\title{
Systematic review and meta-analysis of third-line salvage therapy for the treatment of advanced non-small-cell lung cancer: A meta-analysis of randomized controlled trials
}

\author{
Nan Zhang ${ }^{1}$, Nan Guo ${ }^{2}$, Liang Tian ${ }^{3}$ and Zhigang Miao ${ }^{3}$ \\ ${ }^{1}$ Department of Thoracic Surgery, Cangzhou Central Hospital, Cangzhou, Hebei Province, China \\ ${ }^{2}$ Department of Cardiology, Cangzhou Central Hospital, Cangzhou, Hebei Province, China \\ ${ }^{3}$ Department of Pathology, Cangzhou Central Hospital, Cangzhou, Hebei Province, China \\ Correspondence to: Nan Guo, email: guo_nan2017@126.com \\ Keywords: non-small-cell lung cancer; third-line therapy; heavily pretreated; meta-analysis \\ Received: August 15, 2017 Accepted: October 28, 2017 Epub: March 23, 2018 Published: October 23, 2018
}

Copyright: Zhang et al. This is an open-access article distributed under the terms of the Creative Commons Attribution License 3.0 (CC BY 3.0), which permits unrestricted use, distribution, and reproduction in any medium, provided the original author and source are credited.

\section{ABSTRACT}

Purpose: We performed a systematic review and meta-analysis to investigate the efficacy of third-line treatment for advanced non-small-cell lung cancer (NSCLC).

Materials and Methods: Relevant trials were identified by searching electronic databases and conference meetings. Prospective randomized controlled trials (RCTs) assessing third-line therapy in advanced NSCLC patients were included. Outcomes of interest included overall survival (OS) and progression-free survival (PFS).

Results: A total of 1,985 advanced NSCLC patients received third-line treatment from 11 RCTs were included for analysis. The use of single targeted agent as third-line therapy for advanced NSCLC did not significantly improved PFS (HR $0.75,95 \%$ CI: $0.28-2.04, p=0.58$ ) and OS (HR 1.01, 95\% CI: 0.86-1.17, $p=0.95$ ) when compared to docetaxel alone. In addition, erlotinib-based doublet combination therapy did not significantly improved PFS (HR 0.94, 95\% CI: 0.78-1.13, $p=0.49$ ) and OS (HR 1.08, 95\% CI: $0.78-1.51, p=0.65$ ) in comparison with erlotinib alone.

Conclusions: The findings of this study show that the efficacy of single novel targeted agent is comparable to that of docetaxel alone in terms of PFS and OS for heavily pretreated NSCLC patients. In addition, no survival benefits are obtained from erlotinib-based doublet therapy, thus single agent erlotinib could be recommended as third-line treatment for unselected advanced NSCLC patients.

\section{INTRODUCTION}

Despite a significant improvement in diagnostics and therapy during the past decade, lung cancer remains the leading cancer-related deaths around the world [1]. The majority of lung cancer cases (approximately $80-85 \%$ ) are classified as non-small-cell lung cancer (NSCLC), including squamous carcinoma, adenocarcinoma and large cell carcinoma [2]. Only $30 \%$ of NSCLC patients are resectable at the initial diagnosis, while the remaining $70 \%$ of NSCLC have metastatic or locally advanced disease at time of diagnosis. Palliative chemotherapy and/or radiotherapy represent the standard of care for these patients. Until now, platinum based doublets with third generation agents remains the standard of first line advanced NSCLC treatment [3-5]. However, most patients receiving front-line chemotherapy would eventually become refractory to chemotherapy or experience disease progression after a certain period of time. Currently, two cytotoxic agent docetaxel and pemetrexed and the biologic agent erlotinib have been approved as secondline treatment for advanced NSCLC patients $[3,6]$. Two previously published trials demonstrate that docetaxel is superior to best support care (BSC), vinorelbine, or ifosfamide, in terms of survival benefits and quality of life $(\mathrm{QoL})$ for the treatment of advanced NSCLC patients previously treated with platinum-based chemotherapy $[7,8]$. In another large non-superiority phase III trials, pemetrexed is compared with docetaxel in patients with good PS (0-2), and the result shows no significant 
difference in overall survival between pemetrexed and docetaxel (8.3 months vs 7.9 months, HR, 0.99; $P=0.226$ ), but with less toxicities of pemetrexed [9]. Erlotinib, the third available option, has proven superior to BSC, significantly improving overall survival (6.7 months versus 4.7 months, $\mathrm{HR}=0.70 ; P<0.001)$ and progression-free survival (2.2 months versus 1.8 months, $\mathrm{HR}=0.61 ; p<0.001$ ) [10]. However, standard therapeutic options beyond second-line treatment are insufficient. To our best knowledge, these is no prospective trials specifically addressing the role of third-line treatment in advanced NSCLC, thus we conduct this meta-analysis of randomized controlled trials reporting survival data of those patients who have already received $\geq 2$ prior regimens to clearly determine the role of third-line treatment in NSCLC.

\section{MATERIALS AND METHODS}

\section{Study design}

We performed this systematic review and metaanalysis according to the Reporting Items for Systematic Reviews and Meta-Analyses (PRISMA) statement guidelines 2009 [11].

\section{Search strategy}

We conducted a comprehensive literature search of public databases including PubMed, EMBASE, and the Cochrane library (up to May 30, 2017). Relevant search keywords including the followings: "non-smallcell lung cancer," "third-line therapy," "pretreated" and "randomized controlled trials." No language restriction was administered. We also conducted a manual search of conference proceedings. All results were input into Endnote X7 reference software (Thomson Reuters, Stamford, CT, US) for duplication exclusion and further reference management (Supplementary Table 1 search strategy for EMBASE).

\section{Study selection}

Clinical trials that met the following criteria were included: (1) prospective phase II or III trials involving NSCLC patients; (2) patients received second or later-line therapy; and (3) available survival data regarding thirdline treatment in advanced NSCLC patients. If multiple publications of the same trial were retrieved or if there was a case mix between publications, only the most recent publication (and the most informative) was included.

\section{Data extraction}

Two independent investigators conducted the data abstraction, and any discrepancy between the reviewers was resolved by consensus. The following information was extracted for each study: first author's name, year of publication, trial phase, number of enrolled subjects, treatment arms, median age, median progression-free survival, and overall survival.

\section{Outcome measures}

A formal meta-analysis was conducted using Comprehensive Meta Analysis software (Version 2.0). The outcome data were pooled and reported as hazard ratio (HR). The primary outcome of interest was OS and secondary outcomes PFS in advanced NSCLC receiving third-line therapy.

\section{Statistical analysis}

All statistical analyses were performed by using Version 2 of the Comprehensive MetaAnalysis program (Biostat, Englewood, NJ). Between-study heterogeneity was estimated using the $\chi^{2}$-based $Q$ statistic [12]. The $I^{2}$ statistic was also calculated to evaluate the extent of variability attributable to statistical heterogeneity between trials. A statistical test with a $p$-value less than 0.05 was considered significant. Study quality was assessed by using the Jadad scale based on the reporting of the studies' methods and results [13].

To assess the potential risk bias of included trials, we used the Cochrane risk of bias tool, which had seven domains including random sequence generation, allocation concealment, blinding of participants and personnel, blinding of outcome assessment, incomplete outcome data, selective reporting and other bias. The classification of the judgment for each domain was low risk of bias, high risk of bias, or unclear risk of bias and two authors independently evaluated the risk of studies.

\section{RESULTS}

\section{Search results}

We initially found 300 relevant citations of treatment therapy in pre-treated NSCLC patients. After excluding review articles, phase I studies, case reports, editorial, letters, commentaries, meta-analyses and systematic review (Figure 1), we retrieved 25 reports for full-text screening. Seven of included trials were not used because these studies only included patients receiving second-line therapy [14-20]. Another seven trials were excluded because these studies did not report survival data of patients received third-line therapy [20-26]. Finally, we selected 11 randomized controlled trials for analysis in the present study [10, 26-35]. Five randomized trials compared erlotinib-based doublet versus erlotinib as third-line therapy in advanced NSCLC [29-31, 33, 35], while the remaining trials investigated single targeted 
agent versus docetaxel/placebo as third-line therapy for advanced NSCLC. A total of 1.958 patients received third-line therapy were included for analysis. Table 1 listed the baseline characteristics of patients and studies. The quality of each included study was roughly assessed according to Jadad scale, and six of the eleven randomized controlled trials were double-blind placebocontrolled trials, thus had Jadad score of 5. Another seven trials were an open-label controlled trials, thus had Jadad score of 3 .

\section{Risk of bias in included studies}

Supplementary Figure 1 and Supplementary Figure 2 showed risk bias in all 11 studies. All of the included studies $(100 \%)$ described random sequence generation. five studies (45\%) described adequate allocation concealment. Seven studies $(63.6 \%)$ described blinding of participants and personnel. Four studies had high risk of bias about blinding of participants and personnel because these four studies were open label trial. Nine studies had a low risk of incomplete outcome data. Although some researches had dropout, the effect of intervention was not affected due to due to the small scale of dropout. Ten studies had low risk of selectively reporting results.

\section{Single agent therapy as third-line therapy}

Three trials reported PFS data of single agent third therapy in NSCLC patients. The pooled hazard ratio for PFS demonstrated that the single agent third therapy in advanced NSCLC patients did not significantly improved PFS giving HR 0.75 (95\% CI: $0.28-2.04, p=0.58$, Figure 2), in comparison with docetaxel/placebo. There was significant heterogeneity between trials $\left(I^{2}=92.0 \%, p<0.001\right)$, and the pooled HR for PFS was performed by using random-effects model. Six trials reported OS data of single targeted agent as third-line therapy in this patient population. The pooled hazard ratio for OS showed that the use of single targeted agent as third therapy did not significantly improved OS giving HR 1.01 (95\% CI: $0.86-1.17, p=0.95$, Figure 3 ), in comparison with docetaxel/placebo. Sub-group analysis according to controlled therapy showed that the use of single targeted agent as third therapy did not significantly improved OS in comparison with docetaxel (HR 1.07, 95\% CI: 0.88-1.31, $p=0.49$ ) or placebo (HR 0.92, 95\%CI: 0.73-1.16, $p=0.47$ ).

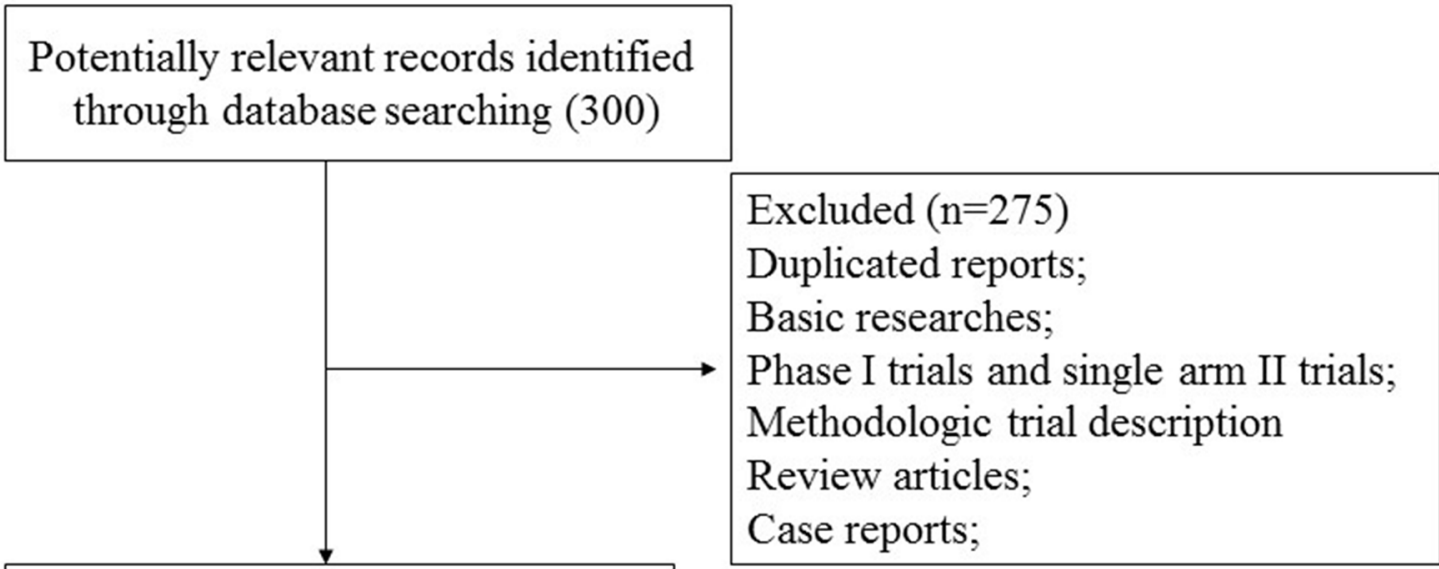

\section{Full text articles assessed for eligibility $(n=25)$}

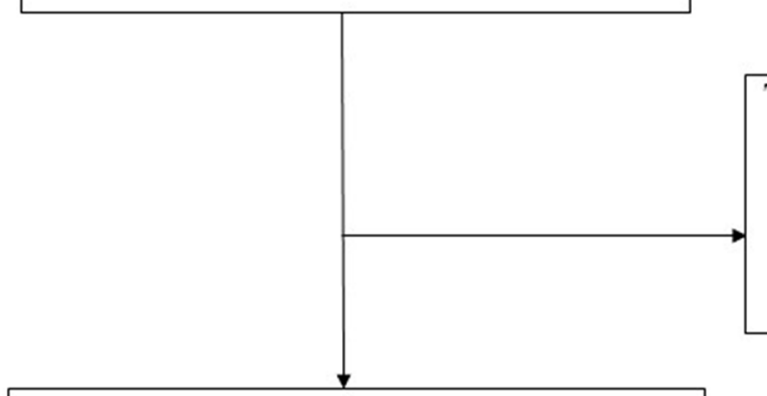

Trials excluded $(n=14)$ :

No available survival data of third-line therapy in NSCLC patients $(n=7)$;

Trials specially assess second-line therapy for advanced NSCLC $(n=7)$;

Eligible trials for meta-analysis $(\mathrm{n}=11)$

Figure 1: Studies eligible for inclusion in the meta-analysis. 


\begin{tabular}{|c|c|c|c|c|c|c|}
\hline Study/year & phase & $\begin{array}{l}\text { No. of elderly } \\
\text { patients }\end{array}$ & treatment regimen & $\begin{array}{l}\text { median } \\
\text { age in all } \\
\text { treatment } \\
\text { cohorts }\end{array}$ & $\begin{array}{l}\text { primary } \\
\text { endpoint }\end{array}$ & $\begin{array}{l}\text { Jadad } \\
\text { Score }\end{array}$ \\
\hline Shepherd F.A. et al/2005 & III & 362 & $\begin{array}{c}\text { erlotinib } 150 \mathrm{mg} \text { qd po } \\
\text { placebo }\end{array}$ & $\begin{array}{l}62 \\
59\end{array}$ & OS & 5 \\
\hline Kim E.S. et al/2008 & III & 226 & $\begin{array}{c}\text { gefitinib } 250 \mathrm{mg} \text { qd po } \\
\text { docetaxel } 75 \mathrm{mg} / \mathrm{m}^{2}\end{array}$ & $\begin{array}{l}61 \\
60\end{array}$ & OS & 3 \\
\hline Maruyama R. et al/2008 & III & 75 & $\begin{array}{c}\text { gefitinib } 250 \mathrm{mg} \text { qd po } \\
\text { docetaxel } 60 \mathrm{mg} / \mathrm{m}^{2}\end{array}$ & $\begin{array}{l}\text { NR } \\
\text { NR }\end{array}$ & OS & 3 \\
\hline Sequist L.V. et al/2011 & II & 34 & $\begin{array}{l}\text { Tivantinib +erlotinib } \\
150 \mathrm{mg} \text { qd po } \\
\text { Placebo+erlotinib } \\
150 \mathrm{mg} \text { qd po }\end{array}$ & 62 & PFS & 5 \\
\hline Miller V.A. et al/2012 & $\mathrm{IIb} / \mathrm{III}$ & 159 & $\begin{array}{c}\text { afatinib } 50 \mathrm{mg} \text { qd po } \\
\text { placebo }\end{array}$ & $\begin{array}{l}58 \\
59\end{array}$ & OS & 5 \\
\hline Scagliotti G.V. et al/2012 & III & 269 & $\begin{array}{l}\text { Sunitinib +erlotinib } \\
150 \mathrm{mg} \text { qd po } \\
\text { Placebo+erlotinib } \\
150 \mathrm{mg} \text { qd po }\end{array}$ & 61 & OS & 5 \\
\hline Spigel D.R. et al/2013 & II & 22 & $\begin{array}{l}\text { Onartuzumab +erlotinib } \\
150 \mathrm{mg} \text { qd po } \\
\text { Placebo +erlotinib } \\
150 \mathrm{mg} \text { qd po }\end{array}$ & 63 & PFS & 5 \\
\hline Borghaei H. et al/2015 & III & 66 & $\begin{array}{l}\text { Nivolumab } 3 \mathrm{mg} / \mathrm{kg} \\
\text { q.2.w. } \\
\text { docetaxel } 75 \mathrm{mg} / \mathrm{m}^{2}\end{array}$ & $\begin{array}{l}61 \\
64\end{array}$ & OS & 3 \\
\hline Scagliotti G. et al/2015 & III & 354 & $\begin{array}{l}\text { Tivantinib +erlotinib } \\
150 \mathrm{mg} \text { qd po } \\
\text { Placebo +erlotinib } 150 \\
\text { mg qd po }\end{array}$ & 62 & OS & 5 \\
\hline Rittmeyer A. et al/2017 & III & 210 & $\begin{array}{c}\text { Atezolizumab } 1200 \mathrm{mg} \\
\text { docetaxel } 75 \mathrm{mg} / \mathrm{m}^{2}\end{array}$ & $\begin{array}{l}63 \\
64\end{array}$ & OS & 3 \\
\hline Spigel D.R. et al/2017 & III & 181 & $\begin{array}{l}\text { Onartuzumab +erlotinib } \\
150 \mathrm{mg} \text { qd po } \\
\text { Placebo +erlotinib } \\
150 \mathrm{mg} \text { qd po }\end{array}$ & 62 & OS & 5 \\
\hline
\end{tabular}

Abbreviations: OS, overall survival; PFS, progression-free survival; NR, not reported.

\section{Erlotinib-based combination as third therapy}

Four included trials comparing erlotinib-based doublet versus erlotinib alone as third-line therapy reported survival data. The pooled hazard ratio for PFS demonstrated that erlotinib-based doublet combination therapy in heavily treated NSCLC patients did not significantly improved PFS (0.94, 95\% CI: 0.78-1.13, $p=$ 0.49 , Figure 4) and OS (HR 1.08, 95\% CI: 0.78-1.51, $p=$ 0.65 , Figure 5) when compared to erlotinib alone.

\section{Publication bias}

We did not perform publication bias analysis due to limited randomized controlled trials in the present study.

\section{DISCUSSION}

Until now, platinum-based doublet chemotherapy represents the gold standard in the treatment of 
Study name

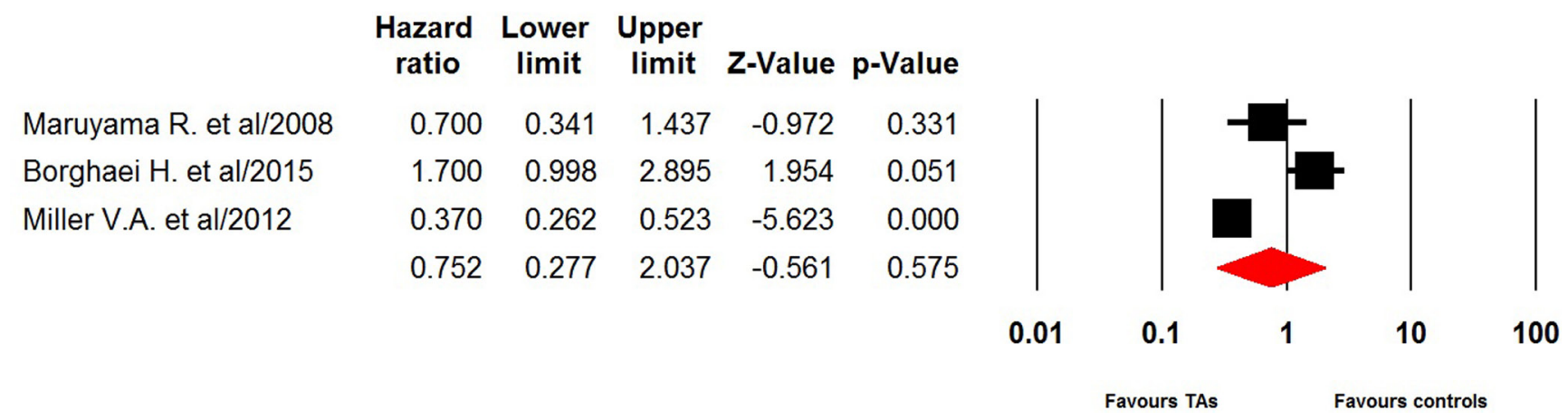

Figure 2: Random-effect model of hazard ratio (95\%CI) of PFS associated with single targeted agent versus placebo/ docetaxel in NSCLC patients.

Group by Study name
docetaxel Kim E.S. et al/2008
docetaxel Maruyama R. et al/2008
docetaxel Borghaei H. et al/2015
docetaxel Rittmeyer A. et al/2017
docetaxel
placebo Shepherd F.A. et al/2005
placebo Miller V.A. et al/2012
placebo
Overall

Statistics for each study

0.01
Hazard ratio and $95 \% \mathrm{Cl}$

Hazard Lower Upper

ratio limit limit Z-Value $p$-Value

$\begin{array}{lllll}1.380 & 1.027 & 1.854 & 2.136 & 0.033\end{array}$

$\begin{array}{lllll}0.750 & 0.402 & 1.398 & -0.905 & 0.365\end{array}$

$\begin{array}{lllll}1.340 & 0.734 & 2.445 & 0.954 & 0.340\end{array}$

$\begin{array}{lllll}0.800 & 0.571 & 1.121 & -1.295 & 0.195\end{array}$

$\begin{array}{lllll}1.073 & 0.880 & 1.308 & 0.698 & 0.485\end{array}$

$\begin{array}{lllll}0.800 & 0.581 & 1.102 & -1.367 & 0.172\end{array}$

$\begin{array}{lllll}1.070 & 0.762 & 1.503 & 0.390 & 0.696\end{array}$

$\begin{array}{lllll}0.917 & 0.726 & 1.158 & -0.728 & 0.467\end{array}$

$\begin{array}{lllll}1.005 & 0.864 & 1.168 & 0.061 & 0.951\end{array}$ $\mid$

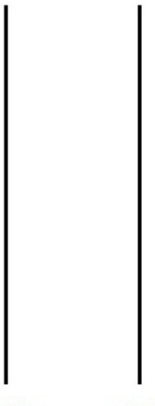

0.1

Favours TAs

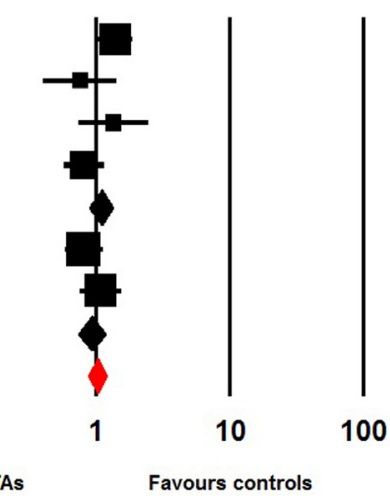

Favours controls

Figure 3: Fixed-effect model of hazard ratio $(95 \% \mathrm{CI})$ of $\mathrm{OS}$ associated with single targeted agent versus placebo/ docetaxel in NSCLC patients.

Study name

$\begin{array}{lcccccc} & \begin{array}{c}\text { Hazard } \\ \text { ratio }\end{array} & \begin{array}{c}\text { Lower } \\ \text { limit }\end{array} & \begin{array}{c}\text { Upper } \\ \text { limit }\end{array} & \text { z-Value } & \text { p-Value } \\ \text { Sequist L.V. et al/2011 } & 0.980 & 0.562 & 1.707 & -0.071 & 0.943 \\ \text { Scagliotti G.V.et al/2012 } & 0.822 & 0.622 & 1.087 & -1.376 & 0.169 \\ \text { Spigel D.R. et al/2013 } & 0.673 & 0.347 & 1.306 & -1.171 & 0.242 \\ \text { Spigel D.R. et al/2017 } & 1.170 & 0.855 & 1.600 & 0.983 & 0.326 \\ & 0.936 & 0.776 & 1.129 & -0.690 & 0.490\end{array}$

Hazard ratio and $95 \% \mathrm{Cl}$

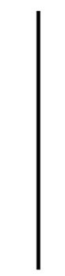

0.01

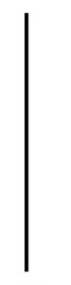

0.1

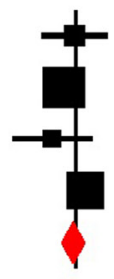

1
10

100

Favours erlotinib

Figure 4: Fixed-effects model of hazard ratio $(95 \% \mathrm{CI})$ of PFS associated with erlotinib-based doublet versus erlotinib in NSCLC patients. 
chemotherapy-naïve advanced NSCLC [36]. Unfortunately, most of NSCLC patients ultimately suffer from disease progression. In the past few years, the second-line treatment options for advanced NSCLC have been established. Two chemotherapeutic agents, docetaxel and pemetrexed, and the biological drug erlotinib are the only three drugs approved for clinical use in this setting, achieving a median 8-10 months of overall survival $[6,37]$. However, clinicians inevitably encounter difficulty in treating patients with advanced NSCLC who experience a relapse following second-line treatment with these drugs, and it has been reported that more than $38 \%$ of advanced NSCLC patients who received first-line chemotherapy could receive third-line chemotherapy [38]. In addition, this patient population has been increasing, and there is an urgent need to clearly define the role of third-line treatment for advanced NSCLC [39, 40]. To our best knowledge, there is no prospective randomized controlled trial specifically assessed the role of third-line treatment in advanced NSCLC patients, we thus conduct this metaanalysis of randomized controlled trials with predefined sub-group analysis to determine the role of third-line treatment for this patient population.

A total of 1,985 advanced NSCLC patients received third-line treatment from 11 RCTs are included for analysis. The quality of included trials is high. Seven of the eleven trials are double-blinded, placebo-controlled trials and the other four trials are open-label randomized controlled trials. The pooled results show that single targeted agent as third-line therapy for advanced NSCLC does not significantly improve PFS (HR $0.75,95 \% \mathrm{CI}$ : $0.28-2.04, p=0.58$ ) and OS (HR 1.01, 95\% CI: 0.86 $1.17, p=0.95)$ when compared to placebo/docetaxel alone. In the setting of the third-line therapy, single agent docetaxel is one of the most frequently used regimens for heavily pretreated NSCLC patients. Several retrospective studies have demonstrated that advanced NSCLC patients with good performance status might benefit from cytotoxic chemotherapy including docetaxel alone [41-44], but these findings need to be confirmed in prospective randomized trials. As a result, the American Society of
Clinical Oncology (ASCO) clinical practice guideline could not make a recommendation for or against using cytotoxic agents as third-line therapy [6]. In consistent with previous findings, sub-group analysis according to controlled therapy shows that the use of single targeted agent as third therapy does not significantly improve OS in comparison with docetaxel alone (HR 1.07, 95\% CI: $0.88-1.31, p=0.49)$. As a result, prospective randomized controlled specially comparing novel targeted agent with docetaxel as third-line therapy for advanced NSCLC are clearly needed.

Until now, erlotinib is the only recommended third-line therapy for patients who have not received prior erlotinib or gefitinib according to ASCO clinical practice guideline [3]. In the present study, four included trials investigate whether the addition of a novel target to erlotinib would improve survival in heavily pretreated NSCLC patients. The pooled results show that no obvious benefits are obtained from combination therapy in terms of PFS $(0.94, p=0.49)$ and OS (HR 1.08, $p=0.65)$ when compared to erlotinib alone. Based on our findings, single agent erlotinib remains the recommended third-line therapy for advanced NSCLC patients who not received prior erlotinib or gefitinib.

There are several limitations exist in this analysis. First, this meta-analysis only includes published trials, and a meta-analysis of individual level data might define more clearly treatment benefits in specific subgroups. For instance, anti-EGFR TKIs have been shown to have excellent treatment outcome in patients with EGFR mutation, and we are unable to investigate whether the survival benefit from third-line erlotinib is similar in NSCLC patients with or without EGFR mutation. Second, none of the included trials report the toxicities of thirdline therapy in heavily pretreated NSCLC patients. Thus, we could not answer whether the use of erlotinib-based doublet combination therapy in this patient population would increase the toxicities in comparison with erlotinib alone. Third, different targeted agents, including EGFRTKIs and immune check point inhibitors, are included for analysis in the present study, which might increase
Study name

$\begin{array}{lrrrrrr} & \begin{array}{c}\text { Hazard } \\ \text { ratio }\end{array} & \begin{array}{c}\text { Lower } \\ \text { limit }\end{array} & \begin{array}{c}\text { Upper } \\ \text { limit }\end{array} & \text { Z-Value } & \text { p-Value } \\ \text { Scagliotti G.V.et al/2012 } & 0.833 & 0.631 & 1.100 & -1.287 & 0.198 \\ \text { Scagliotti G. et al/2015 } & 1.030 & 0.791 & 1.341 & 0.219 & 0.826 \\ \text { Spigel D.R. et al/2017 } & 1.620 & 1.071 & 2.451 & 2.283 & 0.022 \\ & 1.081 & 0.775 & 1.508 & 0.459 & 0.647\end{array}$

Hazard ratio and $95 \% \mathrm{Cl}$

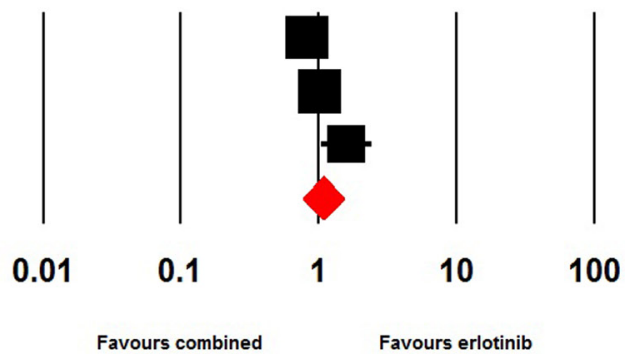

Figure 5: Fixed-effects model of hazard ratio (95\% CI) of OS associated with erlotinib-based doublet versus erlotinib in NSCLC patients. 
the heterogeneity among included trials. Fourthly, our analyses are based on subgroup data from individual trials and thus lack power. Also, none of the combination treatments examined in the meta-analysis are licensed. Finally, publication bias is an important issue for metaanalysis because trials with positive results are more likely to be published. Our paper do not assess publication bias due to limited trials included for analysis.

\section{CONCLUSIONS}

In conclusion, this is the first-meta-analysis specifically assessing the efficacy of third-line therapy in the treatment of advanced NSCLC patients. The results of our study suggest that the efficacy of single novel targeted agent is comparable to that of docetaxel alone in terms of PFS and OS for heavily pretreated NSCLC patients. In addition, no survival benefits are obtained from erlotinib-based doublet therapy, thus single agent erlotinib could be recommended as third-line treatment for unselected advanced NSCLC patients. Further studies are recommended to specifically investigate the efficacy and toxicities of third-line therapy in the treatment of advanced NSCLC patients.

\section{CONFLICTS OF INTEREST}

All authors declare that they have no potential conflicts of interests.

\section{FUNDING}

None.

\section{REFERENCES}

1. Jemal A, Bray F, Center MM, Ferlay J, Ward E, Forman D. Global cancer statistics. CA Cancer J Clin. 2011; 61:69-90. https://doi.org/10.3322/caac.20107.

2. Iacono D, Chiari R, Metro G, Bennati C, Bellezza G, Cenci M, Ricciuti B, Sidoni A, Baglivo S, Minotti V, Crinò L. Future options for ALK-positive non-small cell lung cancer. Lung Cancer. 2015; 87:211-19. https://doi.org/10.1016/j. lungcan.2014.12.017.

3. Azzoli CG, Baker S Jr, Temin S, Pao W, Aliff T, Brahmer J, Johnson DH, Laskin JL, Masters G, Milton D, Nordquist L, Pfister DG, Piantadosi S, et al, and American Society of Clinical Oncology. American Society of Clinical Oncology Clinical Practice Guideline update on chemotherapy for stage IV nonsmall-cell lung cancer. J Clin Oncol. 2009; 27:6251-66. https://doi.org/10.1200/JCO.2009.23.5622.

4. Bareschino MA, Schettino C, Rossi A, Maione P, Sacco PC, Zeppa R, Gridelli C. Treatment of advanced non small cell lung cancer. J Thorac Dis. 2011; 3:122-33.
5. NSCLC Meta-Analyses Collaborative Group. Chemotherapy in addition to supportive care improves survival in advanced non-small-cell lung cancer: a systematic review and metaanalysis of individual patient data from 16 randomized controlled trials. J Clin Oncol. 2008; 26:4617-25. https://doi.org/10.1200/JCO.2008.17.7162.

6. Masters GA, Temin S, Azzoli CG, Giaccone G, Baker S Jr, Brahmer JR, Ellis PM, Gajra A, Rackear N, Schiller JH, Smith TJ, Strawn JR, Trent D, Johnson DH, and American Society of Clinical Oncology Clinical Practice. Systemic Therapy for Stage IV Non-Small-Cell Lung Cancer: American Society of Clinical Oncology Clinical Practice Guideline Update. J Clin Oncol. 2015; 33:3488-515. https://doi.org/10.1200/JCO.2015.62.1342. Erratum in: ERRATA. [J Clin Oncol. 2016].

7. Shepherd FA, Dancey J, Ramlau R, Mattson K, Gralla R, O’Rourke M, Levitan N, Gressot L, Vincent M, Burkes R, Coughlin S, Kim Y, Berille J. Prospective randomized trial of docetaxel versus best supportive care in patients with non-small-cell lung cancer previously treated with platinumbased chemotherapy. J Clin Oncol. 2000; 18:2095-103. https://doi.org/10.1200/JCO.2000.18.10.2095.

8. Fossella FV, DeVore R, Kerr RN, Crawford J, Natale RR, Dunphy F, Kalman L, Miller V, Lee JS, Moore M, Gandara D, Karp D, Vokes E, et al. Randomized phase III trial of docetaxel versus vinorelbine or ifosfamide in patients with advanced non-small-cell lung cancer previously treated with platinumcontaining chemotherapy regimens. The TAX 320 Non-Small Cell Lung Cancer Study Group. J Clin Oncol. 2000; 18:2354 62. https://doi.org/10.1200/JCO.2000.18.12.2354.

9. Hanna N, Shepherd FA, Fossella FV, Pereira JR, De Marinis F, von Pawel J, Gatzemeier U, Tsao TC, Pless M, Muller T, Lim HL, Desch C, Szondy K, et al. Randomized phase III trial of pemetrexed versus docetaxel in patients with non-small-cell lung cancer previously treated with chemotherapy. J Clin Oncol. 2004; 22:1589-97. https://doi.org/10.1200/JCO.2004.08.163.

10. Shepherd FA, Rodrigues Pereira J, Ciuleanu T, Tan EH, Hirsh V, Thongprasert S, Campos D, Maoleekoonpiroj S, Smylie M, Martins R, van Kooten M, Dediu M, Findlay $\mathrm{B}$, et al, and National Cancer Institute of Canada Clinical Trials Group. Erlotinib in previously treated non-smallcell lung cancer. N Engl J Med. 2005; 353:123-32. https://doi.org/10.1056/NEJMoa050753.

11. Liberati A, Altman DG, Tetzlaff J, Mulrow C, Gøtzsche PC, Ioannidis JP, Clarke M, Devereaux PJ, Kleijnen J, Moher D. The PRISMA statement for reporting systematic reviews and meta-analyses of studies that evaluate healthcare interventions: explanation and elaboration. BMJ. 2009; 339:b2700. https://doi.org/10.1136/bmj.b2700.

12. Zintzaras E, Ioannidis JP. Heterogeneity testing in metaanalysis of genome searches. Genet Epidemiol. 2005; 28:123-37. https://doi.org/10.1002/gepi.20048.

13. Moher D, Pham B, Jones A, Cook DJ, Jadad AR, Moher M, Tugwell P, Klassen TP. Does quality of reports of 
randomised trials affect estimates of intervention efficacy reported in meta-analyses? Lancet. 1998; 352:609-13. https://doi.org/10.1016/S0140-6736(98)01085-X.

14. Herbst RS, Ansari R, Bustin F, Flynn P, Hart L, Otterson GA, Vlahovic G, Soh CH, O'Connor P, Hainsworth J. Efficacy of bevacizumab plus erlotinib versus erlotinib alone in advanced non-small-cell lung cancer after failure of standard first-line chemotherapy (BeTa): a double-blind, placebo-controlled, phase 3 trial. Lancet. 2011; 377:184654. https://doi.org/10.1016/S0140-6736(11)60545-X.

15. Groen HJ, Socinski MA, Grossi F, Juhasz E, Gridelli C, Baas P, Butts CA, Chmielowska E, Usari T, Selaru P, Harmon C, Williams JA, Gao F, et al. A randomized, double-blind, phase II study of erlotinib with or without sunitinib for the second-line treatment of metastatic non-small-cell lung cancer (NSCLC). Ann Oncol. 2013; 24:2382-89. https://doi.org/10.1093/annonc/mdt212.

16. Reck M, Kaiser R, Mellemgaard A, Douillard JY, Orlov S, Krzakowski M, von Pawel J, Gottfried M, Bondarenko I, Liao M, Gann CN, Barrueco J, Gaschler-Markefski B, Novello S, and LUME-Lung 1 Study Group. Docetaxel plus nintedanib versus docetaxel plus placebo in patients with previously treated non-small-cell lung cancer (LUME-Lung 1): a phase 3, double-blind, randomised controlled trial. Lancet Oncol. 2014; 15:143-55. https://doi.org/10.1016/ S1470-2045(13)70586-2.

17. Herbst RS, Baas P, Kim DW, Felip E, Pérez-Gracia JL, Han JY, Molina J, Kim JH, Arvis CD, Ahn MJ, Majem M, Fidler MJ, de Castro G Jr, et al. Pembrolizumab versus docetaxel for previously treated, PD-L1-positive, advanced non-small-cell lung cancer (KEYNOTE-010): a randomised controlled trial. Lancet. 2016; 387:1540-50. https://doi.org/10.1016/S0140-6736(15)01281-7.

18. Ramalingam SS, Jänne PA, Mok T, O’Byrne K, Boyer MJ, Von Pawel J, Pluzanski A, Shtivelband M, Docampo LI, Bennouna J, Zhang H, Liang JQ, Doherty JP, et al. Dacomitinib versus erlotinib in patients with advanced-stage, previously treated non-small-cell lung cancer (ARCHER 1009): a randomised, double-blind, phase 3 trial. Lancet Oncol. 2014; 15:1369-78. https://doi.org/10.1016/S1470-2045(14)70452-8.

19. Ellis PM, Shepherd FA, Millward M, Perrone F, Seymour L, Liu G, Sun S, Cho BC, Morabito A, Leighl NB, Stockler MR, Lee CW, Wierzbicki R, et al, and NCIC CTG, and Australasian Lung Cancer Trials Group, and NCI Naples Clinical Trials Unit. Dacomitinib compared with placebo in pretreated patients with advanced or metastatic nonsmall-cell lung cancer (NCIC CTG BR.26): a double-blind, randomised, phase 3 trial. Lancet Oncol. 2014; 15:1379-88. https://doi.org/10.1016/S1470-2045(14)70472-3.

20. Shaw AT, Kim DW, Nakagawa K, Seto T, Crinó L, Ahn MJ, De Pas T, Besse B, Solomon BJ, Blackhall F, Wu YL, Thomas M, O'Byrne KJ, et al. Crizotinib versus chemotherapy in advanced ALK-positive lung cancer. N Engl J Med. 2013; 368:2385-94. https://doi.org/10.1056/ NEJMoa1214886.
21. Ramalingam SS, Spigel DR, Chen D, Steins MB, Engelman JA, Schneider CP, Novello S, Eberhardt WE, Crino L, Habben K, Liu L, Jänne PA, Brownstein CM, Reck M. Randomized phase II study of erlotinib in combination with placebo or R1507, a monoclonal antibody to insulinlike growth factor-1 receptor, for advanced-stage nonsmall-cell lung cancer. J Clin Oncol. 2011; 29:4574-80. https://doi.org/10.1200/JCO.2011.36.6799.

22. Spigel DR, Burris HA 3rd, Greco FA, Shipley DL, Friedman EK, Waterhouse DM, Whorf RC, Mitchell RB, Daniel DB, Zangmeister J, Bass JD, Hainsworth JD. Randomized, double-blind, placebo-controlled, phase II trial of sorafenib and erlotinib or erlotinib alone in previously treated advanced non-small-cell lung cancer. J Clin Oncol. 2011; 29:2582-89. https://doi.org/10.1200/JCO.2010.30.7678.

23. Witta SE, Jotte RM, Konduri K, Neubauer MA, Spira AI, Ruxer RL, Varella-Garcia M, Bunn PA Jr, Hirsch FR. Randomized phase II trial of erlotinib with and without entinostat in patients with advanced non-smallcell lung cancer who progressed on prior chemotherapy. J Clin Oncol. 2012; 30:2248-55. https://doi.org/10.1200/ JCO.2011.38.9411.

24. Karampeazis A, Voutsina A, Souglakos J, Kentepozidis N, Giassas S, Christofillakis C, Kotsakis A, Papakotoulas P, Rapti A, Agelidou M, Agelaki S, Vamvakas L, Samonis G, et al. Pemetrexed versus erlotinib in pretreated patients with advanced non-small cell lung cancer: a Hellenic Oncology Research Group (HORG) randomized phase 3 study. Cancer. 2013; 119:2754-64. https://doi.org/10.1002/cncr.28132.

25. Kawaguchi T, Ando M, Asami K, Okano Y, Fukuda M, Nakagawa H, Ibata H, Kozuki T, Endo T, Tamura A, Kamimura M, Sakamoto K, Yoshimi M, et al. Randomized phase III trial of erlotinib versus docetaxel as second- or third-line therapy in patients with advanced non-small-cell lung cancer: Docetaxel and Erlotinib Lung Cancer Trial (DELTA). J Clin Oncol. 2014; 32:1902-08. https://doi. org/10.1200/JCO.2013.52.4694.

26. Miller VA, Hirsh V, Cadranel J, Chen YM, Park K, Kim SW, Zhou C, Su WC, Wang M, Sun Y, Heo DS, Crino L, Tan EH, et al. Afatinib versus placebo for patients with advanced, metastatic non-small-cell lung cancer after failure of erlotinib, gefitinib, or both, and one or two lines of chemotherapy (LUX-Lung 1): a phase 2b/3 randomised trial. Lancet Oncol. 2012; 13:528-38. https://doi.org/10.1016/S1470-2045(12)70087-6.

27. Kim ES, Hirsh V, Mok T, Socinski MA, Gervais R, Wu YL, Li LY, Watkins CL, Sellers MV, Lowe ES, Sun Y, Liao ML, Osterlind K, et al. Gefitinib versus docetaxel in previously treated non-small-cell lung cancer (INTEREST): a randomised phase III trial. Lancet. 2008; 372:1809-18. https://doi.org/10.1016/S0140-6736(08)61758-4.

28. Maruyama R, Nishiwaki Y, Tamura T, Yamamoto N, Tsuboi M, Nakagawa K, Shinkai T, Negoro S, Imamura F, Eguchi K, Takeda K, Inoue A, Tomii K, et al. Phase III study, V-15-32, of gefitinib versus docetaxel in previously treated Japanese 
patients with non-small-cell lung cancer. J Clin Oncol. 2008; 26:4244-52. https://doi.org/10.1200/JCO.2007.15.0185.

29. Sequist LV, von Pawel J, Garmey EG, Akerley WL, Brugger W, Ferrari D, Chen Y, Costa DB, Gerber DE, Orlov S, Ramlau R, Arthur S, Gorbachevsky I, et al. Randomized phase II study of erlotinib plus tivantinib versus erlotinib plus placebo in previously treated non-small-cell lung cancer. J Clin Oncol. 2011; 29:3307-15. https://doi.org/10.1200/JCO.2010.34.0570.

30. Scagliotti GV, Krzakowski M, Szczesna A, Strausz J, Makhson A, Reck M, Wierzbicki RF, Albert I, Thomas M, Miziara JE, Papai ZS, Karaseva N, Thongprasert S, et al. Sunitinib plus erlotinib versus placebo plus erlotinib in patients with previously treated advanced non-small-cell lung cancer: a phase III trial. J Clin Oncol. 2012; 30:2070 78. https://doi.org/10.1200/JCO.2011.39.2993.

31. Spigel DR, Ervin TJ, Ramlau RA, Daniel DB, Goldschmidt JH Jr, Blumenschein GR Jr, Krzakowski MJ, Robinet G, Godbert B, Barlesi F, Govindan R, Patel T, Orlov $\mathrm{SV}$, et al. Randomized phase II trial of Onartuzumab in combination with erlotinib in patients with advanced nonsmall-cell lung cancer. J Clin Oncol. 2013; 31:4105-14. https://doi.org/10.1200/JCO.2012.47.4189.

32. Borghaei H, Paz-Ares L, Horn L, Spigel DR, Steins M, Ready NE, Chow LQ, Vokes EE, Felip E, Holgado E, Barlesi F, Kohlhäufl M, Arrieta $\mathrm{O}$, et al. Nivolumab versus Docetaxel in Advanced Nonsquamous Non-SmallCell Lung Cancer. N Engl J Med. 2015; 373:1627-39. https://doi.org/10.1056/NEJMoa1507643.

33. Scagliotti G, von Pawel J, Novello S, Ramlau R, Favaretto A, Barlesi F, Akerley W, Orlov S, Santoro A, Spigel D, Hirsh V, Shepherd FA, Sequist LV, et al. Phase III Multinational, Randomized, Double-Blind, PlaceboControlled Study of Tivantinib (ARQ 197) Plus Erlotinib Versus Erlotinib Alone in Previously Treated Patients With Locally Advanced or Metastatic Nonsquamous NonSmall-Cell Lung Cancer. J Clin Oncol. 2015; 33:2667-74. https://doi.org/10.1200/JCO.2014.60.7317.

34. Rittmeyer A, Barlesi F, Waterkamp D, Park K, Ciardiello F, von Pawel J, Gadgeel SM, Hida T, Kowalski DM, Dols $\mathrm{MC}$, Cortinovis DL, Leach J, Polikoff J, et al, and OAK Study Group. Atezolizumab versus docetaxel in patients with previously treated non-small-cell lung cancer (OAK): a phase 3, open-label, multicentre randomised controlled trial. Lancet. 2017; 389:255-65. https://doi.org/10.1016/S01406736(16)32517-X.

35. Spigel DR, Edelman MJ, O’Byrne K, Paz-Ares L, Mocci S, Phan S, Shames DS, Smith D, Yu W, Paton VE, Mok T. Results From the Phase III Randomized Trial of Onartuzumab
Plus Erlotinib Versus Erlotinib in Previously Treated Stage IIIB or IV Non-Small-Cell Lung Cancer: METLung. J Clin Oncol. 2017; 35:412-20. https://doi.org/10.1200/JCO.2016.69.2160.

36. Socinski MA, Evans T, Gettinger S, Hensing TA, VanDam Sequist L, Ireland B, Stinchcombe TE. Treatment of stage IV non-small cell lung cancer: Diagnosis and management of lung cancer, 3rd ed: American College of Chest Physicians evidence-based clinical practice guidelines. Chest. 2013 (Suppl 5); 143:e341S-e368S. https://doi.org/10.1378/chest.12-2361.

37. Corrales L, Nogueira A, Passiglia F, Listi A, Caglevic C, Giallombardo M, Raez L, Santos E, Rolfo C. SecondLine Treatment of Non-Small Cell Lung Cancer: Clinical, Pathological, and Molecular Aspects of Nintedanib. Front Med (Lausanne). 2017; 4:13. https://doi.org/10.3389/ fmed.2017.00013.

38. Asahina H, Sekine I, Horinouchi H, Nokihara H, Yamamoto N, Kubota K, Tamura T. Retrospective analysis of third-line and fourth-line chemotherapy for advanced non-small-cell lung cancer. Clin Lung Cancer. 2012; 13:39-43. https://doi. org/10.1016/j.cllc.2011.06.008.

39. Ying Geng Z, Chang Jiao S, Cui Liu S, Li Y, Feng Liu Z, Qing Zhang G, Jie Wang L, Qu F. Third-line therapy in advanced non-small cell lung cancer. J BUON. 2013; 18:899-907.

40. De Grève J, Decoster L, van Brummelen D, Geers C, Schallier D. Is there a third line option after chemotherapy and TKI failure in advanced non-small cell lung cancer? Transl Lung Cancer Res. 2012; 1:152-54.

41. Girard N, Jacoulet P, Gainet M, Elleuch R, Pernet D, Depierre A, Dalphin JC, Westeel V. Third-line chemotherapy in advanced non-small cell lung cancer: identifying the candidates for routine practice. J Thorac Oncol. 2009; 4:1544-49. https://doi.org/10.1097/JTO.0b013e3181bbf223.

42. Chen YM, Shih JF, Fan WC, Wu CH, Chou KT, Tsai CM, Lee YC, Perng RP, Whang-Peng J. Third-line or fourth-line chemotherapy in non-small-cell lung cancer patients with relatively good performance status. J Chin Med Assoc. 2011; 74:209-14. https://doi.org/10.1016/j.jcma.2011.03.005.

43. Song Z, Yu Y, Chen Z, Lu S. Third-line therapy for advanced non-small-cell lung cancer patients: feasible drugs for feasible patients. Med Oncol. 2011 (Suppl 1); 28:S60512. https://doi.org/10.1007/s12032-010-9753-3.

44. Biswas B. Erlotinib versus docetaxel as second- or thirdline therapy in patients with advanced non-small-cell lung cancer in the era of personalized medicine. J Clin Oncol. 2015; 33:524. https://doi.org/10.1200/JCO.2014.57.5621. 